() 2018 - ISSN 1807-2577

\title{
Rubbing ethanol and time of use: critical factors compromising latex gloves structure
}

\author{
Desinfecção com etanol e tempo de uso: fatores críticos que comprometem a \\ estrutura das luvas de látex
}

\author{
Isaac Jordão DE SOUZA ARAÚJO ${ }^{a}$ (i), Talita Malini CARLETTI ${ }^{\text {(D) }}$, \\ Fabianna da Conceição Dantas de MEDEIROS' ${ }^{(1)}$, Isabela Pinheiro Cavalcanti LIMA ${ }^{\text {c* }}$ (1) \\ aUNICAMP - Universidade Estadual de Campinas, Faculdade de Odontologia de Piracicaba, Departamento de \\ Odontologia Restauradora, Piracicaba, SP, Brasil \\ bUNICAMP - Universidade Estadual de Campinas, Faculdade de Odontologia de Piracicaba, Departamento de Prótese e \\ Periodontia, Piracicaba, SP, Brasil \\ 'UERN - Universidade do Estado do Rio Grande do Norte, Departamento de Odontologia, Caicó, RN, Brasil
}

\begin{abstract}
How to cite: De Souza Araújo IJ, Carletti TM, Medeiros FCD, Lima IPC. Rubbing ethanol and time of use: critical factors compromising latex gloves structure. Rev Odontol UNESP. 2021;50:e20200023. https://doi.org/10.1590/1807-2577.02321
\end{abstract}

\begin{abstract}
Resumo
Introdução: Para proteger pacientes e profissionais de doenças, o uso de equipamentos de proteção individual é obrigatório, principalmente no ambiente odontológico. 0 risco de microperfurações das luvas é iminente ao usar instrumentos cortantes ou na tentativa de limpar as luvas durante longos procedimentos clínicos. Objetivo: Este estudo avaliou a integridade das luvas cirúrgicas e de procedimento antes do uso clínico e esclareceu se o atrito com a solução desinfetante modifica a morfologia e integridade da superfície. Material e método: Amostras de luvas de quatro marcas diferentes foram divididas em dois grupos: (1) Luvas cirúrgicas ( $\mathrm{n}=260$ ) e (2) Luvas descartáveis não estéreis (n = 260). As luvas foram cortadas e colocadas em arco de Ostby, de modo que três soluções - água destilada, etanol $70^{\circ}$, etanol $96^{\circ}$ foram esfregadas com um cotonete. Após 30s, 5, 10 e 15 minutos de fricção das soluções, as amostras foram verificadas utilizando um microscópio eletrônico de varredura. Os tamanhos dos poros foram medidos pelo software Image J. Resultado: Independentemente das marcas, todas as luvas foram significativamente afetadas por soluções e períodos de avaliação. Em geral, maiores alterações foram evidenciadas com o uso do etanol $70^{\circ} \mathrm{e} 96^{\circ}$, e maiores diâmetros dos poros foram observados quando comparados à água destilada. Conclusão: Esfregar soluções desinfetantes aumenta o tamanho dos poros das luvas e o tempo influenciou negativamente sua qualidade.
\end{abstract}

Descritores: Luvas de proteção; látex; desinfecção das mãos; porosidade; biosegurança, dentista.

\begin{abstract}
Introduction: Personal protective equipment is mandatory to protect patients and professionals from diseases, especially in the dental environment. The risk of gloves micro-perforations is imminent when using sharp instruments or cleaning them up during lengthy clinical procedures. Objective: This study evaluated the integrity of sterile and non-sterile gloves before clinical use and clarified whether friction with disinfectant solution modifies surface morphology and integrity. Material and method: Samples of gloves from four different brands were divided into two groups: (1) Sterile surgical gloves (n=260) and (2) Non-sterile gloves $(n=260)$. They were scissored and placed in Ostby's arch so that three solutions - distilled water, ethanol $70^{\circ}$, ethanol $96^{\circ}$ - were rubbed with a cotton swab. After 30s, 5, 10, and 15 minutes of solution rubbing, samples were verified by a Scanning Electron Microscope. The pore sizes were measured by Image J software. Result: Regardless of the brands, all gloves have been significantly affected by solutions and assessment periods. In general, remarkable changes were evident with ethanol $70^{\circ}$ and $96^{\circ}$, and higher pore diameters were observed compared to distilled water. Conclusion: Rubbing disinfectant solutions increases gloves' pores sizes, and time negatively influenced its quality.
\end{abstract}

Descriptors: Protective gloves; latex; hand disinfection; porosity; biosafety; dentist. 


\section{INTRODUCTION}

Among health professionals, dental practitioners stand out for exposure to a highly aggressive microbial universe during regular clinical procedures ${ }^{1}$. Recently, the coronavirus disease (COVID-19) global outbreak aroused the attention for new alternative biosafety guidelines in the dental environment2,3. For this, it is well known that personal protective equipment (PPE) is recommended as a standard biosafety protocol to protect patients and health professionals from cross-infection ${ }^{2-4}$.

The use of high-speed rotatory equipment, handling sharp instruments, and direct contact with blood and saliva ${ }^{5-10}$ are sometimes unavoidable. The risk of gloves micro-perforations is

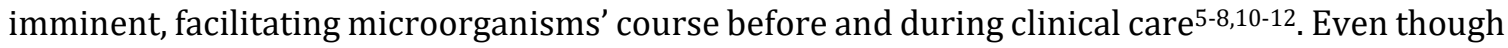
surgical sterile or non-sterile gloves provide a physical barrier in clinical procedures ${ }^{6,8,10-12}$, it is mandatory to conduct comprehensive tests to ensure the quality of these materials as an effective barrier against pathogens ${ }^{5-19}$. Among those methods, electronic devices ${ }^{20,21}$, pressurized air influx, looking for blood in the surgeon's hand 6 , water filling, and bacterial assays have been applied8,11,12,22. However, most tests are performed after gloves usage, which often neglects the previous presence of micro-perforations, which could expose professionals to a high risk of contamination ${ }^{6,12}$.

In addition to micro-perforations, there is a concern regarding the integrity of gloves for timeconsuming procedures, $6,13,18,23$. Some studies reported that the number of perforations significantly increases after a two-hour clinical procedure $6,10,13,18$. Also, the contact with organic solvents, such as alcohol, acetone, and even methacrylate, critically affects the integrity of gloves $5,14,16,18,19,23$. As a result, lengthy procedures and contact with organic solvents would reduce the quality of the physical barrier provided by the gloves. However, to the best of our knowledge, literature has no studies verifying the effects of solvents increasing the size of previous microperforations on disposable gloves.

Therefore, this study aimed to evaluate the integrity of sterile surgical and non-sterile gloves before clinical use and clarify whether friction with disinfectant solution modifies surface morphology and integrity. Finally, we verified how time contributes to reducing gloves' quality as a physical barrier against pathogens.

\section{MATERIAL AND METHOD}

In this in vitro study, new latex gloves, unexpired, from four different brands were tested and divided into groups: 1) Supermax (Curitiba, PR, Brazil); 2) Sensitex (Mucambo S.A, Ilhéus, BA, Brazil); 3) Descarpack (São Paulo, SP, Brazil); 4) Volk do Brasil (Araucária, PR, Brazil). In total, 260 sterile surgical gloves and 260 non-sterile gloves for all the tested brands were used, totalizing 520 latex gloves per group. Three solutions were also used: distilled water, ethanol $70^{\circ}$, ethanol $96^{\circ}$ (ethanol $96^{\circ}$ and $70^{\circ}$, Santa $\mathrm{Cruz}^{\circledR}$, São Paulo, SP, Brazil), in four periods of assessment, 30 seconds, 5 minutes, 10 minutes, and 15 minutes. Therefore, it was considered 20 samples per disinfectant solution and another five samples for the control group, totalizing 65 samples per brand in each group (Figure 1). It was believed that the late effects of dryness caused by solutions on latex and the extended pore sizes on gloves could be evidenced in these assessment periods.

Before testing, the presence of macro-perforations was verified through visual inspection. Gloves with visible defects were excluded from the samples and replaced by non-defective ones. Samples were prepared by a single operator, who scissored the gloves in squares of $10 \mathrm{~cm} \mathrm{x}$ $10 \mathrm{~cm}$, in the parts corresponding to the palm or back of the hands. After stretching and positioning in Ostby's arch, the solutions were rubbed over each sample, separately, with a cotton swab for the 30s. In the control group, no solution was applied. 


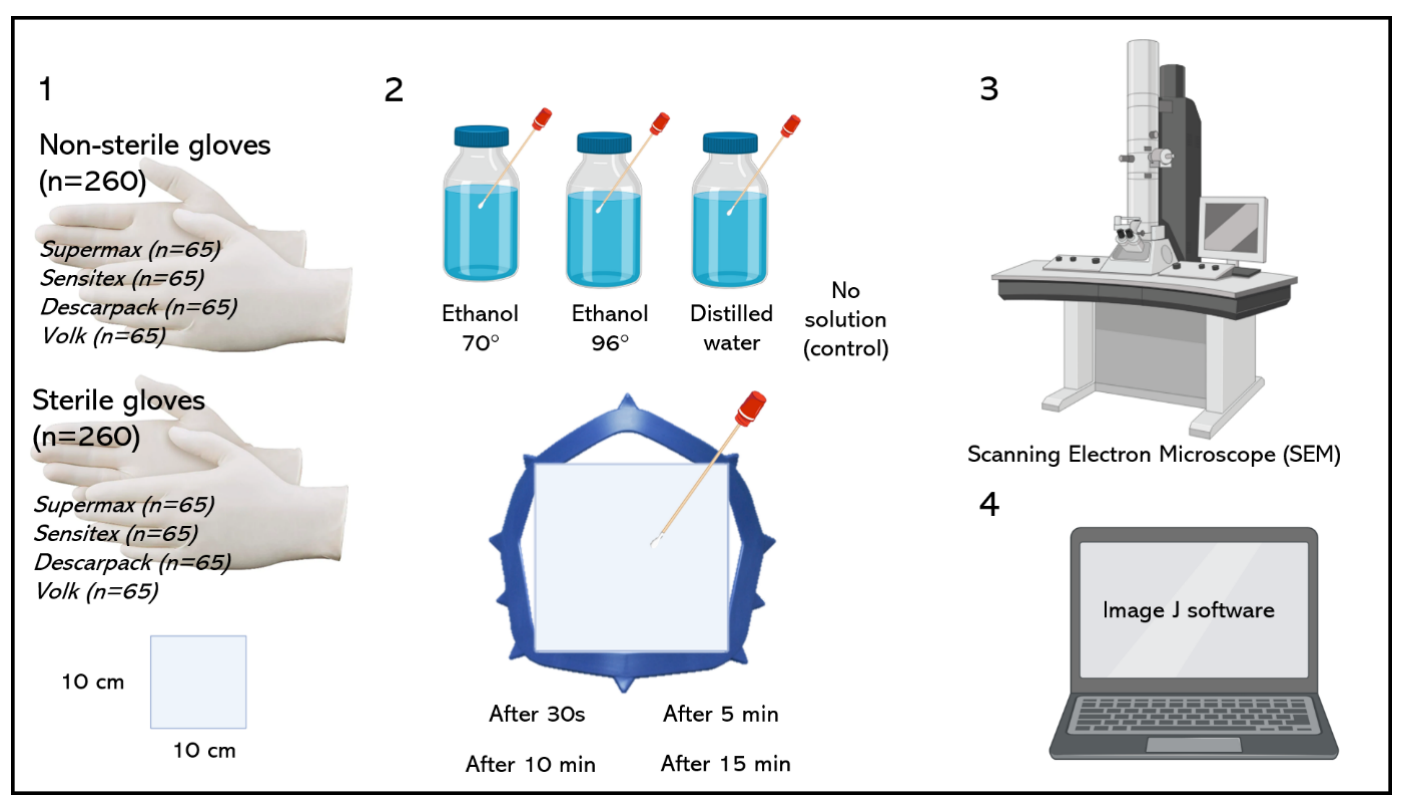

Figure 1. Experimental design scheme. (1) Four brands were tested, including non-sterile and sterile gloves (total of 520 gloves), which were cut into samples of $10 \times 10 \mathrm{~cm}$. (2) The samples were stretched and placed in Ostby's arch, so that the disinfectant solutions of ethanol $70^{\circ}$ and $96^{\circ}$, and distilled water were rubbed over the gloves using a cotton swab. (3) Scanning electron microscope (SEM) was used to verify the size of the pores $30 \mathrm{~s}, 5 \mathrm{~min}, 10 \mathrm{~min}, 15 \mathrm{~min}$ after solutions rubbing. (4) Finally, Image $\mathrm{J}$ software was adopted to calculate the pore size measurements $(\mu \mathrm{m})$.

A Scanning Electron Microscope (SEM) (Phillips XL30 - ESEM, Amsterdam, NL), in low-vacuum mode, was used to analyze the microstructure of the samples (pores formation) 30 seconds, 5 minutes, 10 minutes, and 15 minutes after rubbing solutions. After that, images were digitally opened using Image J software (NIH, Bethesda, MD, USA), and the pore sizes were measured $(\mu \mathrm{m})$. Five pores were measured in different regions of each sample.

\section{Statistical analysis}

As the Shapiro-Wilk test demonstrated data homogeneity, three-way ANOVA verified the interaction between materials, solutions, and assessment periods. Bonferroni and Dunnet's posthoc tests confirmed where the differences occur. Multiple t-tests were used to compare surgical and non-sterile gloves for each brand, solution, and periods of assessment separately. All analyses were performed using SPSS software (version 21, IBM Statistics, Armonk, NY, USA). The significance level was set to $\mathrm{p}<0.05$.

\section{RESULT}

The average pore diameters of sterile and non-sterile gloves after rubbing ethanol and distilled water over time are displayed in Tables 1 and 2, respectively. No statistical differences between brands were found; results are presented as global averages. Regardless of brands, all gloves have been significantly affected by solutions and assessment periods. In general, remarkable changes were evident with ethanol $70^{\circ}$ and $96^{\circ}$, and higher pore diameters were observed compared to distilled water. Statistical differences between the two types of ethanol were evidenced only after $15 \mathrm{~min}$ for non-sterile gloves and $10 \mathrm{~min}$ for sterile surgical gloves. Also, the longer the assessment period after usage of ethanol to disinfect gloves, the higher the pore diameter for both sterile surgical and non-sterile gloves. 
Table 1. Average pore diameters $(\mu \mathrm{m})$ of sterile surgical gloves in different periods of assessment, after rubbing solutions

\begin{tabular}{|c|c|c|}
\hline Periods & Solutions & Average diameters (SD \pm ) \\
\hline \multirow[t]{2}{*}{$\mathrm{N} / \mathrm{A}$} & Control (no solution) & $0.2944(0.003)^{* *}$ \\
\hline & Distilled water\# & $0.355(0.002)^{\mathrm{a}}$ \\
\hline \multirow[t]{3}{*}{ After 30s A } & Ethanol $70^{\circ} \neq$ & $0.464(0.002)^{\mathrm{a}}$ \\
\hline & Ethanol $96^{\circ} \neq$ & $0.484(0.002)^{\mathrm{a}}$ \\
\hline & Distilled water\# & $0.364(0.001)^{\mathrm{a}}$ \\
\hline \multirow[t]{3}{*}{ After 5 min ${ }^{B}$} & Ethanol $70^{\circ} \neq$ & $0.935(0.002)^{\mathrm{b}}$ \\
\hline & Ethanol $96^{\circ} \neq$ & $0.922(0.002)^{b}$ \\
\hline & Distilled water\# & $0.368(0.001)^{\mathrm{a}}$ \\
\hline \multirow[t]{3}{*}{ After $10 \min ^{\mathrm{C}}$} & Ethanol $70^{\circ} \neq$ & $1.980(0.036)^{\mathrm{c}}$ \\
\hline & Ethanol $96^{\circ *}$ & $1.883(0.031)^{\mathrm{c}}$ \\
\hline & Distilled water\# & $0.376(0.002)^{\mathrm{a}}$ \\
\hline \multirow[t]{2}{*}{ After 15 min D } & Ethanol $70^{\circ} \neq$ & $2.548(0.044)^{\mathrm{d}}$ \\
\hline & Ethanol $96^{\circ} \neq$ & $2.482(0.071)^{\mathrm{d}}$ \\
\hline
\end{tabular}

Different capital letters represent statistical differences between periods of assessment $(\mathrm{p}<0.05)$. Different lower letters represent statistical differences between the same solution through the different periods of assessment $(\mathrm{p}<0.05)$. Different symbols represent statistical difference between the solutions for the same period $(\mathrm{p}<0.05)$. ${ }^{* *}$ Indicates statistical difference of control group for the $t$ test comparison to all groups and treatment $(\mathrm{p}<0.01)$.

Table 2. Average pore diameters $(\mu \mathrm{m})$ of non-sterile gloves in different periods of assessment, after rubbing solutions

\begin{tabular}{|c|c|c|}
\hline Periods & Solutions & Average diameter (SD \pm ) \\
\hline \multirow[t]{2}{*}{$\mathrm{N} / \mathrm{A}$} & Control (no solution) & $0.5918(0.007)^{* *}$ \\
\hline & Distilled water\# & $0.776(0.006)^{\mathrm{a}}$ \\
\hline \multirow[t]{3}{*}{ After $30 \mathrm{~s}^{\mathrm{A}}$} & Ethanol $70^{\circ} \neq$ & $1.957(0.039)^{\mathrm{a}}$ \\
\hline & Ethanol $96^{\circ} \neq$ & $2.074(0.059)^{\mathrm{a}}$ \\
\hline & Distilled water\# & $0.785(0.009)^{\mathrm{a}}$ \\
\hline \multirow[t]{3}{*}{ After 5 min ${ }^{B}$} & Ethanol $70^{\circ} \neq$ & $3.996(0.074)^{b}$ \\
\hline & Ethanol 96ํ & $3.995(0.042)^{\mathrm{b}}$ \\
\hline & Distilled water\# & $0.788(0.009)^{\mathrm{a}}$ \\
\hline \multirow[t]{3}{*}{ After $10 \min ^{C}$} & Ethanol $70^{\circ} \neq$ & $4.974(0.051)^{c}$ \\
\hline & Ethanol $96^{\circ} \neq$ & $4.970(0.044)^{c}$ \\
\hline & Distilled water\# & $0.797(0.006)^{\mathrm{a}}$ \\
\hline \multirow[t]{2}{*}{ After 15 min ${ }^{D}$} & Ethanol $70^{\circ} \neq$ & $5.990(0.045)^{\mathrm{d}}$ \\
\hline & Ethanol 96** & $5.878(0.049)^{\mathrm{d}}$ \\
\hline
\end{tabular}

Different capital letters represent statistical differences between periods of assessment $(p<0.05)$. Different lower letters represent statistical differences between the same solution through the different periods of assessment $(p<0.05)$. Different symbols represent statistical difference between the solutions for the same time $(\mathrm{p}<0.05)$. ${ }^{* *}$ Indicates statistical difference of control group for the $t$ test comparison to all groups and treatment $(\mathrm{p}<0.01)$.

Complementary to multiple comparisons, sterile surgical gloves presented smaller pore sizes than non-sterile gloves under all comparisons $(\mathrm{p}<0.01)$. 


\section{DISCUSSION}

Gloves constitute some of the mandatory PPE, acting as physical barriers to protect patients and professionals from microorganism contamination during dental clinical procedures ${ }^{1-3}$. Even though these materials' integrity has always been verified, it is ubiquitous to find clinicians that rub alcohol between the gloves during the same-patient appointment. The reasons pointed out in the literature are handling non-sterile equipment and instruments, cleaning up gloves, or avoiding washing the hands during long task periods ${ }^{13}$. Indeed, biosafety standards are not thoroughly followed and deserve massive attention in the dental field. Thus, this study showed the consequences of rubbing ethanol on sterile surgical and non-sterile gloves, simulating the above-mentioned clinical conditions.

The sterile and the non-sterile gloves have shown increased pore diameters after ethanol friction. On the other hand, ethanol concentration did not influence the outcomes, demonstrating that this chemical solution or any other disinfectant solutions with an alcohol-based medium induce microstructural changes and raise the risk of disease exposure and contamination ${ }^{5,14}$. According to Gao et al. ${ }^{5}$ (2016), the tensile strength of gloves decreases after using an isopropanol alcohol-based hand rub compared to an ethanol-based solution. Thus, the physical and mechanical properties of the gloves may be altered with these procedures. In contrast, Birnbach et al. ${ }^{13}$ (2019) did not evidence impairments on the integrity of nitrile gloves after ethanol friction or any other tactile hamper, considering the intervention a practical and viable attempt to reduce pathogen spread.

Moreover, some authors corroborate our findings showing modifications in surface morphology after contact with various solvents $5,14,15,17-19$. Ethanol, acetone, methacrylate, or other substances, such as eugenol, bleaching agents, phosphoric acid, or some drugs, are frequently used in the daily dental routine and have also been associated with changes in the gloves' morphology ${ }^{9,13}$. In addition to the micro-structural changes, the possible diffusion of these chemical solutions, which depends on the extent and duration of contact, and the amount of hand/glove flexions, can cause cross-infection and allergic reactions to contact with potentially toxic materials $14,16,23$. On the other hand, Phalen et al. ${ }^{17}$ (2014) demonstrated that latex gloves showed better results than nitrile and vinyl gloves after chemical permeation of ethyl alcohol.

Curiously, rubbing distilled water on gloves enlarged the pore size compared to the control group for both types of gloves, which leads to the inference that rubbing gloves with an interposed liquid could enhance the pore diameter by creating small perforations on the latex surface. Consequently, the gloves exhibit a pore size compatible with the transit of most viruses and bacteria $^{8,11}$, although no bacterial activity was performed in this study. The bacterial passage through the perforations is correlated with the rigidity or elasticity of the glove material ${ }^{11}$.

Additionally, gloves are not effective protective barriers considering clinical procedures involving contact with contaminated body fluids ${ }^{8-11,22}$ even combined with the other PPE. A previous study suggested that every patient must be considered a potential pathogen transmitter once the oral cavity presents more than seven hundred species of microorganisms ${ }^{8}$. Therefore, it is essential to look upon the diversity of pathogens and communicable diseases in a dental procedure ${ }^{11,22}$. Wearing double gloves, for instance, has been said to be an alternative to avoid disease contamination by infected patients 24 .

Another interesting outcome of our study was the influence of solution usage time on pore size augmentation, which corroborates previous findings $6,10,18,23$. Longer procedures, such as dental surgeries, may increase the risk of cross-infection and bacterial growth by contacting patients' fluids. Likewise, the presence of larger pores in the gloves rubbed with ethanol is of great concern when non-sterile gloves are used $8,9,11$. The acidic composition of sweat and strain on wearing gloves have also been targeted as negative factors, increasing the diameter of the pores ${ }^{6,12}$. The complete visual inspection might be an inadequate and underestimated test to assess the 
integrity of gloves ${ }^{6}$. Once again, it is not indicated to rub the gloves with ethanol solution and use it for lengthy procedures. Some updated biosafety protocols regarding PPE usage recommend changing gloves when they become torn or contaminated ${ }^{2}$, or every 90 minutes $^{22}$, followed by hand hygiene with soap and water ${ }^{2}$. A recent study reported that $98 \%$ of the study participants, including dentists, change the gloves after each patient ${ }^{25}$.

Even though there are no guidelines about what type of dental procedures require surgical gloves, its superior quality is noteworthy in mechanical stability than non-sterile gloves $8,9,11$. Besides better stress support and elongation, the costs, easy handling, and tightness must be evaluated while deciding which type of glove to use in clinical practice. For this study, the tests with surgical gloves, known to be industrially sterile, and the performance of friction with different solutions were intended uniquely to create a comparison between the groups concerning the surface integrity and number of pores. Therefore, this study did not judge sterilization parameters.

Finally, the assessment of solely latex gloves could represent a study withdrawal. Clinicians have constantly adopted nitrile or latex-free gloves as alternative materials to avoid allergies, improve the tactile sensation, or for marketing ideas (colorful gloves). They could reveal different results when a disinfectant solution is applied. Second, although the outcomes may be interpreted with care, as it is an in vitro study, the authors still believe the outcomes could reflect part of the clinical conditions, and it is wise to mention these consequences for adopting biosafety protocols. Further studies may verify the microorganism's count, diffusion of substances, or allergy skin tests over the gloves and other PPE usage by health work professionals.

\section{CONCLUSION}

Rubbing disinfectant solutions increases the gloves' pores sizes of sterile surgical and nonsterile gloves. Time negatively influenced the quality of the gloves, damaging the material microstructure and enlarging the pores, raising risks of cross-infection during more prolonged clinical procedures. Thus, to reduce the chances of cross-infection in clinical practice, it is necessary to follow strict protocols for latex gloves usage.

\section{ACKNOWLEDGEMENTS}

Authors acknowledge the support of a scientific research scholarship to the first author, from National Council for Scientific and Technological Development (CNPq/Brazil), during the development of this research. The authors also thank Probatus Academic Services for English revision.

\section{REFERENCES}

1. Barabari P, Moharamzadeh K. Novel coronavirus (COVID-19) and dentistry - a comprehensive review of literature. Dent J (Basel). 2020 Jun;8(2):53. http://dx.doi.org/10.3390/dj8020053. PMid:32455612.

2. Centers for Disease Control and Prevention - CDC. Coronavirus disease 2019 (COVID-19). Guidance for dental settings. Atlanta, Geórgia: CDC; 2019. p. 1-12.

3. Amato A, Caggiano M, Amato M, Moccia G, Capunzo M, De Caro F. Infection control in dental practice during the COVID-19 pandemic. Int J Environ Res Public Health. 2020 Jul;17(13):4769.

http://dx.doi.org/10.3390/ijerph17134769. PMid:32630735. 
4. GOV.UK. COVID-19 Personal Protective Equipment (PPE) [Internet]. United Kingdom; 2020 [cited 2020 Sept 8 ]. Available from: https://www.gov.uk/government/publications/wuhan-novel-coronavirusinfection-prevention-and-control/covid-19-personal-protective-equipment-ppe

5. Gao P, Horvatin M, Niezgoda G, Weible R, Shaffer R. Effect of multiple alcohol-based hand rub applications on the tensile properties of thirteen brands of medical exam nitrile and latex gloves. J Occup Environ Hyg. 2016;13(12):905-14. http://dx.doi.org/10.1080/15459624.2016.1191640. PMid:27224677.

6. Goldman AH, Haug E, Owen JR, Wayne JS, Golladay GJ. high risk of surgical glove perforation from surgical rotatory instruments. Clin Orthop Relat Res. 2016 Nov;474(11):2513-7. http://dx.doi.org/10.1007/s11999-016-4948-3. PMid:27339122.

7. Hentz RV, Traina GC, Cadossi R, Zucchini P, Muglia MA, Giordani M. The protective efficacy of surgical latex gloves against the risk of skin contamination: how well are the operators protected? J Mater Sci Mater Med. 2000 Dec;11(12):825-32. http://dx.doi.org/10.1023/A:1008913814999. PMid:15348067.

8. Kahar Bador M, Rai V, Yusof MY, Kwong WK, Assadian O. Evaluation of the efficacy of antibacterial medical gloves in the ICU setting. J Hosp Infect. 2015 Jul;90(3):248-52. http://dx.doi.org/10.1016/j.jhin.2015.03.009. PMid:25982193.

9. Oriyama T, Yamamoto T, Yanagihara Y, Nara K, Abe T, Nakajima K, et al. Evaluation of the permeation of antineoplastic agents through medical gloves of varying materials and thickness and with varying surface treatments. J Pharm Health Care Sci. 2017 May;3:13. http://dx.doi.org/10.1186/s40780-0170082-y.

10. Leitgeb J, Schuster R, Yee BN, Chee PF, Harnoss J-C, Starzengruber P, et al. Antibacterial activity of a sterile antimicrobial polyisoprene surgical glove against transient flora following a 2-hours simulated use. BMC Surg. 2015 Jul;15(1):81. http://dx.doi.org/10.1186/s12893-015-0058-5. PMid:26141495.

11. Bardorf MH, Jäger B, Boeckmans E, Kramer A, Assadian O. Influence of material properties on gloves' bacterial barrier efficacy in the presence of microperforation. Am J Infect Control. 2016 Dec;44(12):1645-9. http://dx.doi.org/10.1016/j.ajic.2016.03.070. PMid:27388267.

12. Vogt KL, Tiba A, Lin DG. ADA professional product review: a laboratory analysis of latex examination gloves. J Am Dent Assoc. 2013 Mar;144(3):312-4. http://dx.doi.org/10.14219/jada.archive.2013.0120. PMid:23449908.

13. Birnbach DJ, Thiesen TC, McKenty NT, Rosen LF, Arheart KL, Fitzpatrick M, et al. Targeted use of alcohol-based hand rub on gloves during task dense periods: one step closer to pathogen containment by anesthesia providers in the operating room. Anesth Analg. 2019 Dec;129(6):1557-60. http://dx.doi.org/10.1213/ANE.0000000000004107. PMid:31743175.

14. Baumann M, Rath B, Fischer JH, Iffland R. The permeability of dental procedure and examination gloves by an alcohol based disinfectant. Dent Mater. 2000 Mar;16(2):139-44. http://dx.doi.org/10.1016/S0109-5641(99)00094-9. PMid:11203535.

15. Krzemińska S, Pośniak M, Szewczyńska M. Resistance of gloves and protective clothing materials to permeation of cytostatic solutions. Int J Occup Med Environ Health. 2018 Jan;31(3):341-50. http://dx.doi.org/10.13075/ijomeh.1896.01140. PMid:29171843.

16. Mäkelä EA, Henriks-Eckerman M-L, Ylinen K, Vuokko A, Suuronen K. Permeation tests of glove and clothing materials against sensitizing chemicals using diphenylmethane diisocyanate as an example. Ann Occup Hyg. 2014 Aug;58(7):921-30. http://dx.doi.org/10.1093/annhyg/meu040. PMid:24936578.

17. Phalen RN, Le T, Wong WK. Changes in chemical permeation of disposable latex, nitrile, and vinyl gloves exposed to simulated movement. J Occup Environ Hyg. 2014;11(11):716-21. http://dx.doi.org/10.1080/15459624.2014.908259. PMid:24689368. 
18. Banaee S, Hee SSQ. Glove permeation of chemicals: the state of the art of current practice, part 1: basics and the permeation standards. J Occup Environ Hyg. 2019 Dec;16(12):827-39.

http://dx.doi.org/10.1080/15459624.2019.1678754. PMid:31684851.

19. Ceballos DM, Reeb-Whitaker C, Sasakura M, Dills R, Yost MG. Protection efficacy of gloves against components of the solvent in a sprayed isocyanate coating utilizing a reciprocating permeation panel. Ann Occup Hyg. 2015 Apr;59(3):358-72. http://dx.doi.org/10.1093/annhyg/meu099. PMid:25452292.

20. Banaee S, Hee SSQ. Permeation of limonene through disposable nitrile gloves using a dextrous robot hand. J Occup Health. 2017 Mar;59(2):131-8. http://dx.doi.org/10.1539/joh.16-0179-OA. PMid:28111415.

21. Mathews AR, Que Hee SS. Whole glove permeation of cyclohexanol through disposable nitrile gloves on a dextrous robot hand and comparison with the modified closed-loop ASTM F739 method 1. No fist clenching. J Occup Environ Hyg. 2017 Apr;14(4):243-51. http://dx.doi.org/10.1080/15459624.2016.1250005. PMid:27754775.

22. Harnoß J-C, Partecke L-I, Heidecke C-D, Hübner N-O, Kramer A, Assadian O. Concentration of bacteria passing through puncture holes in surgical gloves. Am J Infect Control. 2010 Mar;38(2):154-8. http://dx.doi.org/10.1016/j.ajic.2009.06.013. PMid:19822380.

23. Banaee S, Hee SSQ. Permeation of ethoxy- and butoxy-ethanols through a disposable nitrile glove. Ind Health. 2020 Jun;58(3):276-81. http://dx.doi.org/10.2486/indhealth.2019-0146. PMid:31685784.

24. Wittmann A, Kralj N, Köver J, Gasthaus K, Lerch H, Hofmann F. Comparison of 4 different types of surgical gloves used for preventing blood contact. Infect Control Hosp Epidemiol. 2010 May;31(5):498502. http://dx.doi.org/10.1086/652158. PMid:20334549.

25. Ramich T, Eickholz P, Wicker S. Work-related infections in dentistry: risk perception and preventive measures. Clin Oral Investig. 2017 Nov;21(8):2473-9. http://dx.doi.org/10.1007/s00784-017-2046-x. PMid:28097434.

\section{CONFLICTS OF INTERESTS}

The authors declare no conflicts of interest.

\section{*CORRESPONDING AUTHOR}

Isabela Pinheiro Cavalcanti Lima, UERN - Universidade do Estado do Rio Grande do Norte, Departamento de Odontologia, Av. Rio Branco, 725, Centro, 59300-000 Caicó, RN, Brasil, e-mail: belapcl@yahoo.com.br

Received: April 2, 2021

Accepted: June 3, 2021 